\title{
The Whole Spectrum of Alcohol-Related Changes in the CNS: Practical MR and CT Imaging Guidelines for Daily Clinical Use
}

\section{Alkoholinduzierte ZNS-Veränderungen in der bildgebenden Diagnostik: Ein CT- und MRT-Leitfaden für die klinische Praxis}

Authors

Affiliations
V. C. Keil' ${ }^{1}$ S. Greschus ${ }^{1}$, C. Schneider ${ }^{2}$, D. R. Hadizadeh ${ }^{1}$, H. H. Schild ${ }^{1}$

Department of Radiology, University Hospital Bonn, Germany

Department of Neurology, University Hospital Bonn, Germany

Key words
brain
CNS
spinal cord
MR imaging

received 24.5.2015 accepted 24.6.2015

Bibliography DOI http://dx.doi.org/ 10.1055/s-0035-1553509 Published online: 2.9.2015 Fortschr Röntgenstr 2015; 187 : 1073-1083 @ Georg Thieme Verlag KG Stuttgart · New York · ISSN 1438-9029

\section{Correspondence}

Dr. Vera Catharina Keil

Department of Radiology, University Hospital Bonn Sigmund-Freud-Straße 25 53127 Bonn Germany

Tel.: ++49/2 28/28715960 Fax: ++49/228/28715598 vera.keil@ukb.uni-bonn.de

\section{Abstract \\ $\nabla$}

Alcohol addiction is the most common drug addiction. Alcohol passes both the placenta as well as the blood-brain barrier and is in multiple ways neurotoxic. Liver diseases and other systemic alcohol-related diseases cause secondary damage to the CNS. Especially in adolescents, even a single episode of severe alcohol intoxication ("binge drinking") may result in life-threatening neurological consequences. Alcohol-related brain and spinal cord diseases derive from multiple causes including impairment of the cellular metabolism, often aggravated by hypovitaminosis, altered neurotransmission, myelination and synaptogenesis as well as alterations in gene expression. Modern radiological diagnostics, MRI in particular, can detect the resulting alterations in the CNS with a high sensitivity. Morphological aspects often strongly correlate with clinical symptoms of the patient. It is less commonly known that many diseases considered as "typically alcohol-related", such as Wernicke's encephalopathy, are to a large extent not alcohol-induced. Visible CNS alterations are thus non-pathognomonic and demand careful evaluation of differential diagnoses. This review article elucidates the pathogenesis, clinical aspects and radiological image features of the most common alcohol-related CNS diseases and their differential diagnoses.

Key Points:

- Alcohol-associated changes in the CNS are common and radiologically assessable.

- They are often subtle and allow multiple differential diagnoses besides alcohol consumption.

- Knowledge of clinical exams and lab results is crucial for diagnostic accuracy.
Citation Format:

- Keil VC, Greschus S, Schneider C etal. The Whole Spectrum of Alcohol-Related Changes in the CNS: Practical MR and CT Imaging Guidelines for Daily Clinical Use. Fortschr Röntgenstr 2015; 187: 1073-1083

\section{Zusammenfassung}

$\nabla$

Alkoholabhängigkeit ist die häufigste Form der Drogenabhängigkeit. Alkohol ist liquor- und plazentagängig und auf komplexe Weise neurotoxisch. Lebererkrankungen und systemische Alkoholfolgeerkrankungen führen zu sekundären ZNS-Schäden. Selbst ein einmaliger Alkoholrausch („binge drinking“) kann, insbesondere für Jugendliche, lebensbedrohliche neurologische Folgen haben. Das Ursachenspektrum alkoholassoziierter Hirn- und Rückenmarkserkrankungen betrifft Störungen des zellulären Energiestoffwechsels durch Alkohol oder alkoholassoziierten Vitaminmangel, die Neurotransmission, die Myelinisierung und Synaptogenese sowie die Genexpression. Im Alltag sind die damit einhergehenden ZNS-Veränderungen mit moderner Schnittbilddiagnostik, insbesondere der MRT, mit hoher Sensitivität nachweisbar und korrelieren oft mit der klinischen Symptomatik des Patienten. Dabei gilt es zu beachten, dass viele als typisch alkoholbedingt bekannte Erkrankungen, wie z. B. die Wernicke-Enzephalopathie und die osmotische Demyelinisierung, zu einem großen Anteil nicht durch Alkoholabusus verursacht werden. Die bildmorphologischen Veränderungen sind demnach nicht pathognomonisch und eine sogfältige klinische Abwägung der Differenzialdiagnosen ist erforderlich. In dieser Übersichtsarbeit werden die Pathogenese, Klinik und Bildmorphologie häufiger alkoholassoziierter ZNS-Erkrankungen und ihrer Differenzialdiagnosen dargelegt. 


\section{Introduction}

$\nabla$

According to current estimates, approximately 9.5 million people in Germany are addicted to alcohol or are at risk. Approx 74,000 people die each year as a result of alcohol consumption [1]. Alcohol consumption is responsible for a significant percentage of all hospitalizations and results in a number of sequelae. In Germany, direct cost for the healthcare system add up to approximately 7.4 billion euros per year [1].

As generally known, the disease affects not only the liver but in particular also the central nervous system (CNS). This is due to the fact that alcohol easily crosses the bloodbrain barrier directly damaging neurons and glial cells. The pathophysiological mechanisms affect in a complex way the energy metabolism of the cells as well as neurotransmission and synaptogenesis. In addition to this primary direct damage, there are secondary damage mechanisms, e.g. metabolic ones. According to the time of occurrence, acute alcohol-related changes are differentiated from the sequelae of alcohol consumption ( $\bullet$ Table 1 ).

Many alcohol-associated changes in the brain and spinal cord can be detected by imaging techniques. This article focuses on their detection by CT and MRI and is aimed to provide a diagnostic guideline for daily clinical routine.

\section{Disease spectra}

Acute alcohol intoxication

In addition to the generally known behavioral changes, alcohol poisoning can result in complications ranging from convulsions and impaired consciousness to coma with respiratory arrest.

Acute alcohol poisoning can cause two rare complications in the CNS that have a similar pathomechanical cause: toxic brain edema and pontine or extrapontine myelinolysis (CPM and EPM), also referred to as osmotic demyelination (OD).

\section{Acute toxic brain edema}

The extremely rare condition of alcohol-induced brain edema is a consequence of osmotic swelling of primarily astrocytes, e.g. due to volume-induced hyponatremia, and by a lack of cellular energy. In addition, alcohol increases the sensitivity of NMDA receptors for glutamate and the integration of water channels into the cell membrane, in particular aquaporin 4 [2, 3]. The higher vulnerability of glial cells explains the predominant location of edema in white matter structures.

CCT is a readily available method suitable for initial examinations of alcohol-intoxicated patients with impaired consciousness. In addition to alcohol-induced brain edema characterized by symmetrical hypodense changes in the white matter and reduced subarachnoid spaces, differential diagnoses can be ruled out and commonly associated trauma sequelae can be detected. With regard to specific changes, CT however has significantly lower sensitivity and specificity. MRI is indicated in clinically complicated cases, e.g. with recurrent convulsions, or suspicion of chronic secondary CNS damage.
Central pontine or extrapontine myelinolysis

Central pontine and extrapontine myelinolysis (also known as osmotic demyelination or osmotic demyelination syndrome, $\bullet$ Fig. 1a-d) were first observed in alcohol-addicted patients during intensified electrolyte substitution [4]. Convulsions and impaired consciousness often occur in the early phase. In case of disease progression over several days, brain stem symptoms, such as bulbar dysfunction, horizontal gaze paresis, and tetraparesis, can occur. The fatality rate is estimated at up to $50 \%$ [5]. Locked-in syndrome can be a late sequela of the disease.

This acute demyelinating disease can be caused by the excessively fast correction of hyponatremia which often occurs under the influence of alcohol, but can also have other causes such as hyperemesis (gravidarum), liver transplantation, or malnutrition. However, non-hyponatremic cases have also been reported [6]. Changes in blood osmolarity induce the transport of osmotically active molecules from the cells into the extracellular space. Cells run low on energy which is then not available to e. g. transport sodium back in the case of sodium substitution. Pontine astrocytes proved to be particularly vulnerable explaining the characteristic distribution pattern of damages in osmotic demyelination [7]. However, all brain regions can be affected in principle.

A cranial CT required for emergency diagnosis on the basis of clinical symptoms can be normal since symptoms often precede the usually subtle imaging changes by days. Therefore, MRI should be performed as quickly as possible in the case of clinical suspicion. However, even MRI can still be normal in the early stages of the disease. Demyelination or initially edema correlate with signal on elevations on T2- and FLAIR-weighted images and possibly diffusion restriction ( $\bullet$ Fig. 1a-d). Isolated extensive symmetrical pontine lesions occur in approx. $50 \%$ of cases. Sparing of the corticospinal tract and white matter of the superficial pontine peripheral zones are typical. Additionally occurring extrapontine lesions affect the cerebellum, the striatum, the thalamus, and more rarely also the cortex and the juxtacortical white matter and the fiber tracts in the region of the inner and outer capsule. Exclusively extrapontine lesions are rare [8]. Blood-brain barrier disruption as well as significantly more rarely, hemorrhages detected evidenced by susceptibility-weighted sequences represent an exacerbation of the finding. Parenchymal defects and volume losses can occur as a result of demyelination.

\section{Acute and chronic hepatic encephalopathy}

Metabolic changes in acute and chronic liver failure cause different forms of hepatic encephalopathy. In acute liver failure, symptoms of cranial pressure can occur with confusion, vomiting, and loss of consciousness, while the chronic form is characterized by permanent mental changes, cognitive impairment, and a hand tremor (asterixis).

The acute form results from hepatic hyperammonemia in during acute liver failure. Astrocytes are rich in glutamate and form glutamine from ammonia and glutamate which has a strong osmotic effect and results in cell swelling and finally apoptosis. Edema of the gray matter (in particular of the insular cortex, the gyrus cinguli, the basal ganglia) occurs in the early stages [9]. 
Table 1 Alcohol-associated changes in the CNS. Overview of the most common pathologies including clinical signs and radiological findings.

\begin{tabular}{|c|c|c|c|c|c|}
\hline \multicolumn{6}{|c|}{ alcohol-related CNS diseases } \\
\hline \multirow[t]{2}{*}{ etiology } & \multicolumn{3}{|l|}{ acute intoxication } & \multicolumn{2}{|l|}{ chronic intoxication } \\
\hline & \multicolumn{2}{|c|}{$\begin{array}{l}\text { - alcohol-dependent lack of ATP } \\
\text { - hypervolemia } \\
\text { - electrolyte imbalance }\end{array}$} & \multirow{2}{*}{$\begin{array}{l}\text { - liver failure } \\
\text { - hyperammonemia } \\
\text { - hyperglutaminemia } \\
\text { - glial swelling } \\
\text { acute hepatic } \\
\text { encephalopathy }\end{array}$} & \multirow{2}{*}{$\begin{array}{l}\text { - liver insufficiency } \\
\text { - hypermanganemia } \\
\text { - manganese in basal } \\
\text { ganglia } \\
\text { chronic hepatic } \\
\text { encephalopathy }\end{array}$} & \multirow{2}{*}{$\begin{array}{l}\text { long-term metabolic } \\
\text { challenge of neurons } \\
\text { and glia and secondary } \\
\text { cell loss } \\
\text { atrophy }\end{array}$} \\
\hline disease & toxic brain edema & $\begin{array}{l}\text { CPM and } \\
\text { EPM (or OD) }\end{array}$ & & & \\
\hline $\begin{array}{l}\text { clinical } \\
\text { symptoms }\end{array}$ & $\begin{array}{l}\text { - altered conscious } \\
\text { - seizures } \\
\text { - tetraparesis } \\
\text { - brainstem symptc }\end{array}$ & & $\begin{array}{l}\text { - asterixis } \\
\text { - psychotic syndrome } \\
\text { - hepatic fetor } \\
\text { - altered consciousness } \\
\text { - seizures }\end{array}$ & $\begin{array}{l}\text { - extrapyramidal Parkinson- } \\
\text { like movement disorders } \\
\text { - asterixis }\end{array}$ & $\begin{array}{l}\text { - cognitive decline } \\
\text { - apathy } \\
\text { - emotional disturbance }\end{array}$ \\
\hline lab tests & $\begin{array}{r}\text { - possibly plasma s } \\
\text { and plasma osmo }\end{array}$ & & $\begin{array}{l}\text { - plasma ammonium often } \uparrow \\
\text { - liver enzymes } \uparrow\end{array}$ & $\begin{array}{l}\text { - plasma manganese } \uparrow \\
\text { - liver enzymes } \uparrow\end{array}$ & $\begin{array}{l}\text { - often aggravated } \\
\text { by depletion of } \\
\text { vit. B stores }\end{array}$ \\
\hline imaging & $\begin{array}{l}\text { - NECT for initial di } \\
\text { - MRI for refined di }\end{array}$ & $\begin{array}{l}\text { ostics } \\
\text { Iostics later }\end{array}$ & & - MRI & - NECT \\
\hline $\begin{array}{l}\text { radiological } \\
\text { signs }\end{array}$ & $\begin{array}{l}\text { - signal in T2w und } \\
\text { (deep WM and co } \\
\text { - most frequently } \mathrm{p} \\
\text { - delayed CE and la } \\
\text { necroses (often in } \\
\text { with seizures) } \\
\text { - diffusion restricti } \\
\text { - hemorrhage in SV } \\
\text { - secondary } \\
\text { atrophy }\end{array}$ & $\begin{array}{l}\text { IlRw: } \uparrow \\
\text { al edema) } \\
\text { tine lesions } \\
\text { lary } \\
\text { ses }\end{array}$ & $\begin{array}{l}\text { - signal in T2W und FLAIRW: } \uparrow \text { (GM and } \\
\text { WM brain edema) } \\
\text { - diffusion restriction } \\
\text { - rarely secondary cortical CE and he- } \\
\text { morrhage } \\
\text { - MRS: elevated glutamine peak in WM }\end{array}$ & $\begin{array}{l}\text { - symmetric lesions in the } \\
\text { pallidum } \\
\text { - more rarely putamen } \\
\text { - signal in native T1w } \uparrow \\
\text { - rarely: } T 2 w \text { and FLAIRw } \\
\text { signal } \uparrow\end{array}$ & $\begin{array}{l}\text { - atrophy of superior } \\
\text { cerebellum } \\
\text { - long-term: global brain } \\
\text { atrophy }\end{array}$ \\
\hline follow-up & $\begin{array}{l}\text { - in case of acute cl } \\
\text { - MRI: in case of inf } \\
\text { - consider MR tract }\end{array}$ & $\begin{array}{l}\text { cal deterioration } \\
\text { tion permanent } \\
\text { aphy in case of }\end{array}$ & $\begin{array}{l}\text { NECT } \\
\text { lesions are detectable } \\
\text { persistent neurological deficit }\end{array}$ & $\begin{array}{l}\text { - adapted to clinical } \\
\text { symptoms } \\
\text { - no short-term } \\
\text { changes expected }\end{array}$ & $\begin{array}{l}\text { - if abstinent from alco- } \\
\text { hol: (partial) normali- } \\
\text { zation expected after } \\
\text { weeks to months }\end{array}$ \\
\hline \multirow[t]{3}{*}{ etiology } & \multicolumn{5}{|c|}{ subacute and chronic hypovitaminoses } \\
\hline & $\begin{array}{l}\text { thiamine deficiency } \\
\text { (vit. B1 deficiency) }\end{array}$ & & & complex vit. B deficiency & $\begin{array}{l}\text { cobalamine deficiency } \\
\text { (vit. B12 deficiency) }\end{array}$ \\
\hline & $\begin{array}{l}\text { N. B.: alcoholism is } \mathrm{C} \\
\text { patients with previo }\end{array}$ & $\begin{array}{l}\text { one risk factor } \\
\text { gastrointestinal }\end{array}$ & $\begin{array}{l}\text { for hypovitaminoses. Patients with chroni } \\
\text { surgery or on special diets as well as pregr }\end{array}$ & $\begin{array}{l}\text { diseases (tumors, HIV, gastro } \\
\text { ant women are also frequentl }\end{array}$ & $\begin{array}{l}\text { intestinal diseases), } \\
\text { affected. }\end{array}$ \\
\hline \multirow[t]{2}{*}{ disease } & Wernicke's enceph & pathy & Korsakoff's syndrome & $\begin{array}{l}\text { Marchiafava-Bignami } \\
\text { syndrome }\end{array}$ & funicular myelosis \\
\hline & \multicolumn{3}{|c|}{ Wernicke-Korsakoff-syndrome } & & \\
\hline $\begin{array}{l}\text { clinical } \\
\text { symptoms }\end{array}$ & $\begin{array}{l}\text { acute triad of: } \\
\text { - nystagmus/oculo } \\
\text { - altered conscious } \\
\text { - cerebellar/gait at } \\
30 \% \text { complete tric } \\
\text { - psychotic sympto }\end{array}$ & $\begin{array}{l}\text { tor palsy } \\
\text { is } \\
\text { (only in }\end{array}$ & $\begin{array}{l}\text { - anterograde amnesia } \\
\text { - confabulations/perseverations } \\
\text { - psychotic symptoms } \\
\text { - sometimes intact long-term memory } \\
\text { - learning difficulty } \\
\text { - apraxia }\end{array}$ & $\begin{array}{l}\text { - disorientation } \\
\text { - amnesia depending on } \\
\text { location, acuity and size: } \\
\text { - altered consciousness } \\
\text { - split-brain symptoms } \\
\text { - occurring also without } \\
\text { alcohol abuse } \\
\text { - severity of symptoms } \\
\text { linked to size of lesions }\end{array}$ & $\begin{array}{l}\text { - loss of proprioception } \\
\text { - gait ataxia } \\
\text { - tendency to fall } \\
\text { - later muscle fatigue, } \\
\text { even tetraplegia } \\
\text { - altered reflexes } \\
\text { - rarely: psychotic } \\
\text { symptoms }\end{array}$ \\
\hline lab tests & $\begin{array}{l}\text { - plasma thiamine } \\
\text { - plasma homocyst } \\
\text { - possibly magnesi }\end{array}$ & & & - plasma homocystein $\uparrow$ & $\begin{array}{l}\text { - plasma homocystein } \uparrow \\
\text { - plasma cobalamine } \downarrow\end{array}$ \\
\hline imaging & $\begin{array}{l}\text { - MRI } \\
\text { - NECT for acutely c } \\
\text { rule out differenti }\end{array}$ & $\begin{array}{l}\text { cal cases to } \\
\text { tiagnoses }\end{array}$ & $-\mathrm{MRI}$ & $\begin{array}{l}\text { - MRI } \\
\text { - NECT for acutely critical } \\
\text { cases to rule out differen- } \\
\text { tial diagnoses }\end{array}$ & $-\mathrm{MRI}$ \\
\hline
\end{tabular}




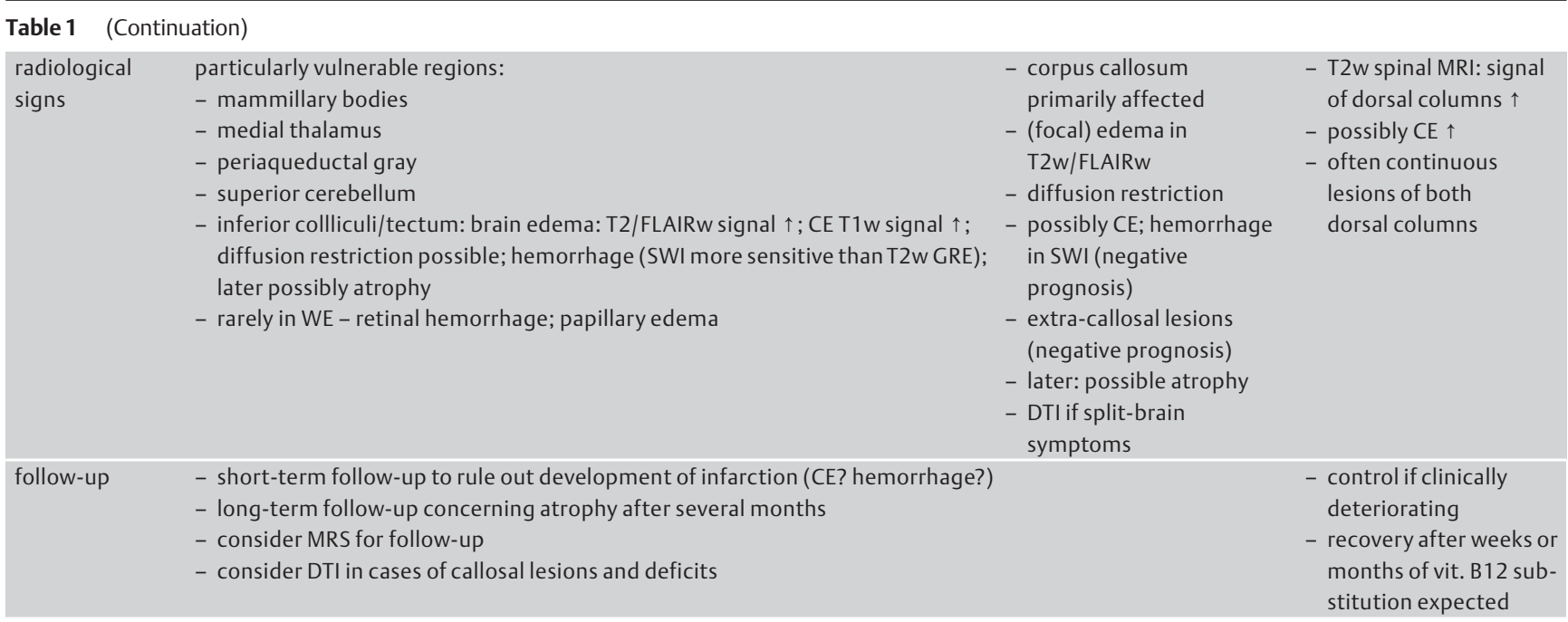

CE - contrast enhancement; CPM - central pontine myelinolysis; DTI - diffusion tensor imaging; EPM - extrapontine myelinolysis; GM - gray matter; KS - Korsakoff‘s syndrome; MRS - MR spectroscopy; NECT - non-enhanced computer tomography; OD - osmotic demyelination; SWI - susceptibility-weighted imaging; WE - Wernicke's encephalopathy; WM - white matter; $\downarrow$ : elevated; $\uparrow:$ lowered.
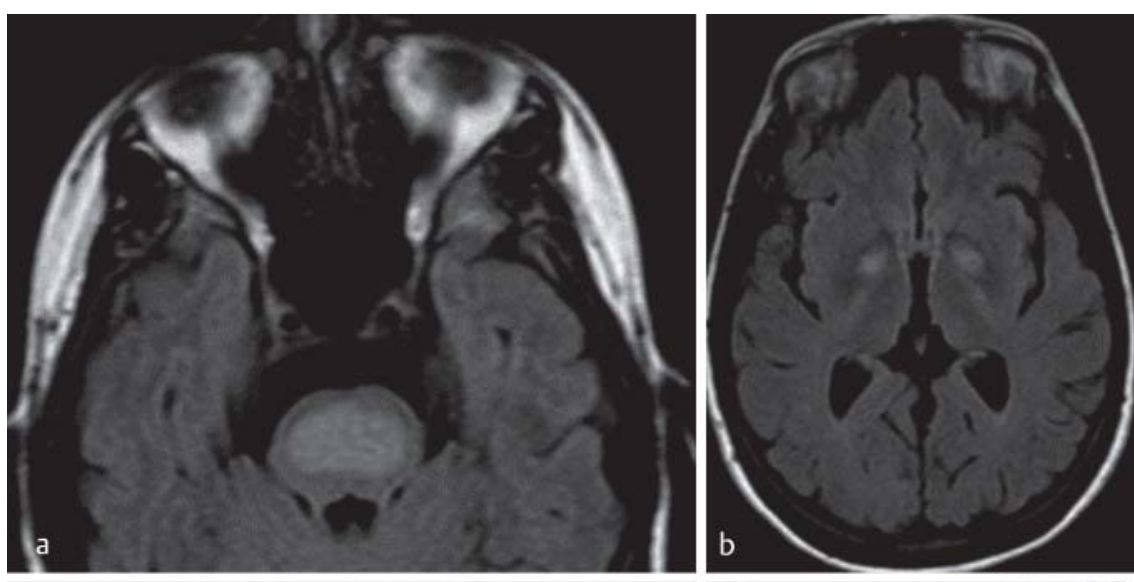

Fig. 1 Acute phase of central pontine myelinolysis. Signal-elevated pons and basal ganglia on FLAIRw images $\mathbf{a}, \mathbf{b}$ as well as restricted diffusion (c; with ADC map, d) in a 36-year-old patient. N.B.: The outer rim of the pontine white matter is spared.
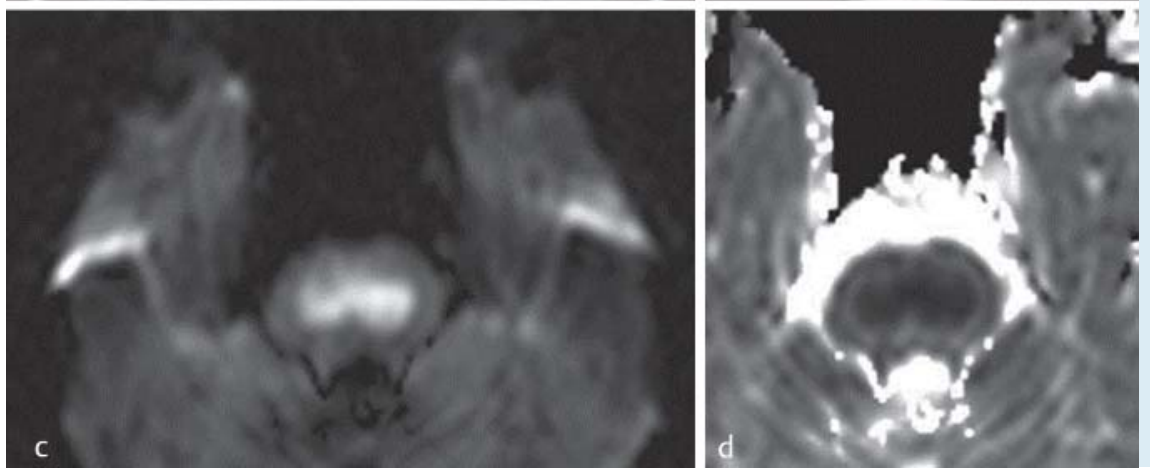

The CNS changes in chronic hepatopathy are due to an accumulation of manganese in the globus pallidus due to decreased hepatic elimination $[10,11]$. Alimentary manganese poisoning without liver insufficiency must be considered as a differential diagnosis. The hypothalamus, anterior midbrain segments, and additional segments of the basal ganglia (substantia innominata, substantia nigra) can also be affected by the accumulations [12].

In the case of encephalopathy due to acute liver failure, symmetrical brain edema can often already be detected on CT.
CNS changes in chronic hepatopathy should be examined via MRI. The accumulated manganese ions cause a signal elevation in the affected nuclei on T1-weighted images without contrast enhancement or a significant signal elevation on T2-weighted images ( $\bullet$ Fig. 2a, b). The thalamus and the putamen are typically not affected. Wilson's disease and $\mathrm{CO}$ poisoning can be considered as differential diagnoses, however demonstrate different symptoms. In contrast to hepatic encephalopathy, contrast enhancement and hemor- 
rhage in the putamen are often observed in cases of $\mathrm{CO}$ poisoning. In Wilson's disease, the thalamus is frequently affected.

\section{Atrophy}

A result of chronic alcohol abuse is cerebral atrophy that is clinically associated with slowly progressing cognitive decline and changes in personality (e.g. stubborness, adynamia and emotional instability). In addition, postural instability and a fine tremor are often seen. In severe cases, there is a tendency toward convulsions. With a similar drinking behavior, the risk of atrophy seems to increase beyond the age of 50 [13].

Alcohol-induced cerebral atrophy has a multifactorial genesis. The proinflammatory alcohol decomposition product acetaldehyde, e.g., fuses with CNS proteins thus promoting apoptosis [14]. Synaptogenesis and cytoskeletal decomposition decelerate under the influence of alcohol [15]. Alcohol also has a genotoxic effect [16]. In the case of chronic alcohol abuse, white matter decreases as a result of inhibition of the remyelination and apoptosis of glial cells proportional to the quantity of alcohol consumed [17]. In comparative studies of alcohol addicted patients with and without thiamine deficiency, atrophy was more pronounced both re- gionally and globally in vitamin-deficient patients. Hence, alcohol-associated thiamine deficiency is considered one of the main causes of cerebral atrophy [18 - 20].

Cerebral atrophy can be diagnosed on NECT ( $\bullet$ Fig. 3a), but MRI allows a more precise evaluation and possibly also quantification. In particular, enlargement of the outer subarachnoid spaces in the region of the superior cerebellum can be observed. Sagitally oriented images are particularly suitable here ( $\bullet$ Fig. 3b, 4a). Metabolic changes can be detected by MR spectroscopy while changes in the fiber tracts can be detected on diffusion tensor MRI (DTI).

Due to the selective vulnerability of some brain regions substance loss occurs in stages even if global cerebral atrophy is ultimately present. The chronologically earliest and generally best known morphological alteration is atrophy of the superior cerebellum, particularly of the superior vermis ( $\bullet$ Fig. 3a, 3b, 4a). However, the frontal white matter is also affected early. Considering gray and white matter separately, atrophy of the gray matter affects the superior portions of the cerebellum and the thalamic nuclei in particular [19, $21,22]$. White matter atrophy is pronounced in the supratentorial frontal, infratentorial pontine, and cerebellar regions $[18,20]$.
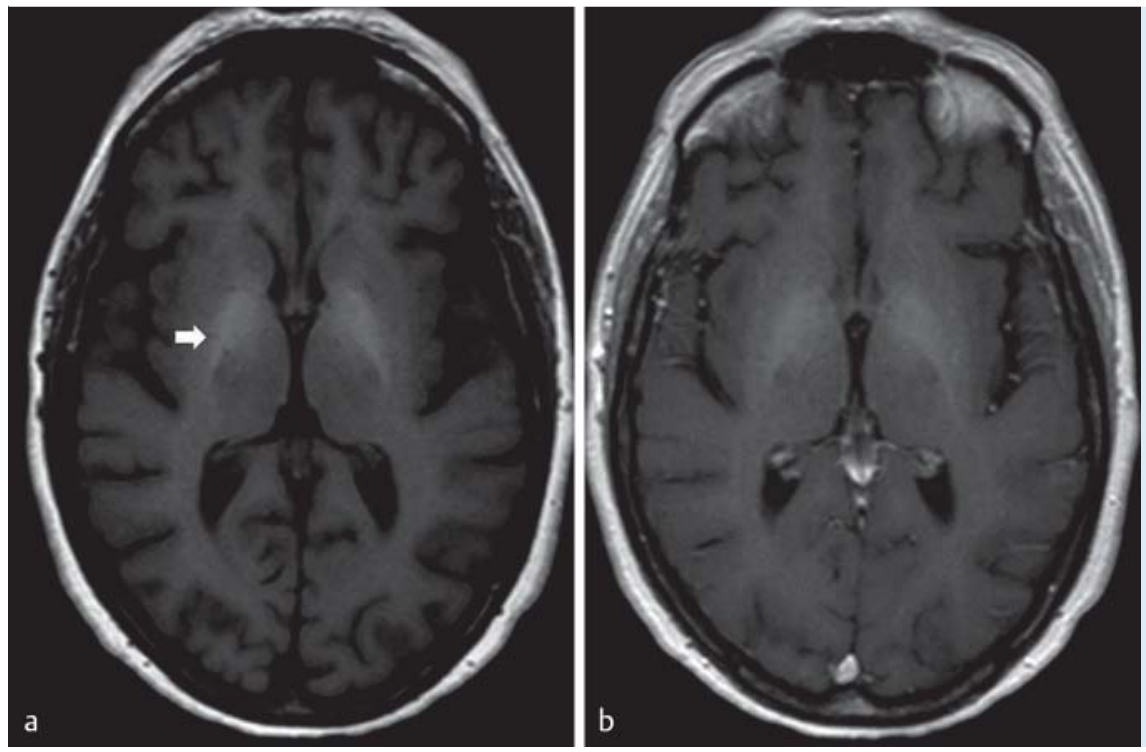

Fig. 2 Chronic hepatic encephalopathy. Symmetrically signal-elevated basal ganglia on native T1w images are the effect of cerebral manganese accumulation in chronic hepatic encephalopathy (arrow, a). N.B. The lesions show no contrast enhancement $\mathbf{b}$.
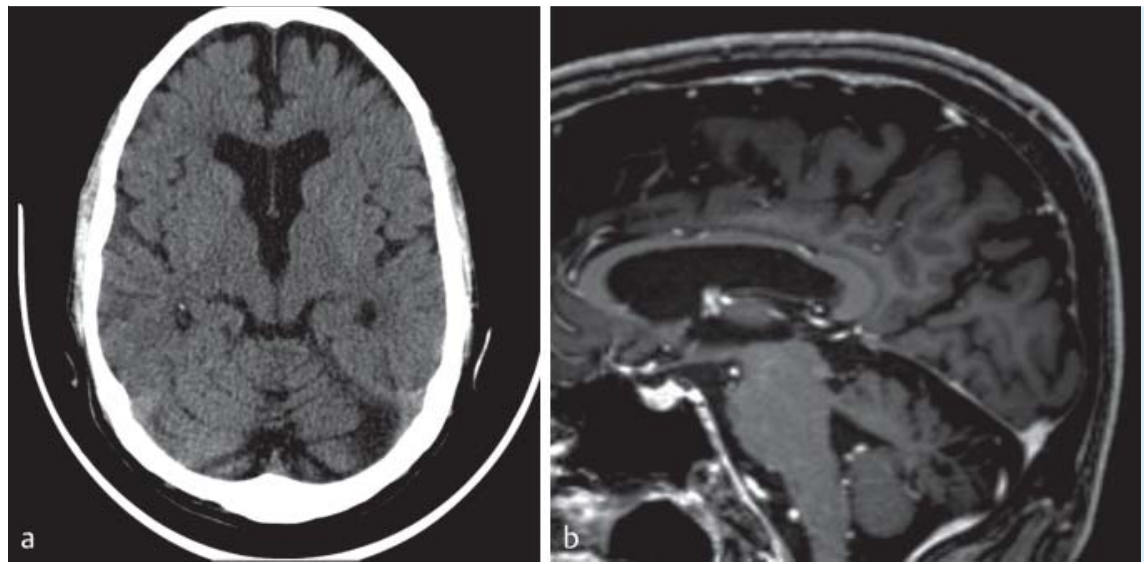

Fig. 3 Atrophy of the superior vermis. The superior parts of the cerebellum are particularly vulnerable to thiamine deficiency. Atrophy of the superior vermis is a frequent finding. In advanced stages atrophy can be diagnosed on NECT showing enlarged exterior CSF spaces a. Sagittally oriented images facilitate diagnosis $\mathbf{b}$. 

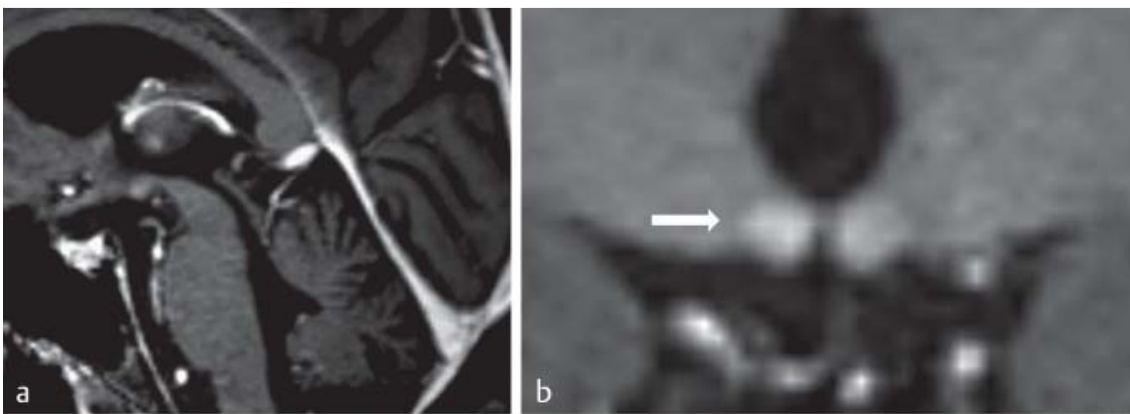

Fig. 4 Wernicke-Korsakoff syndrome. 43-year-old patient with a long-term history of alcoholism with acute oculomotor dysfunction and delirium. Contrast-enhancing mammillary bodies on T1w images a, b. On FLAIRw images signal-elevated medial thalami and periaqueductal gray matter c, d. Further, global brain atrophy (volume-reduced superior vermis, a, and flattened medial thalami, $\mathbf{c}$ as a consequence of chronic alcohol abuse and thiamine deficiency.
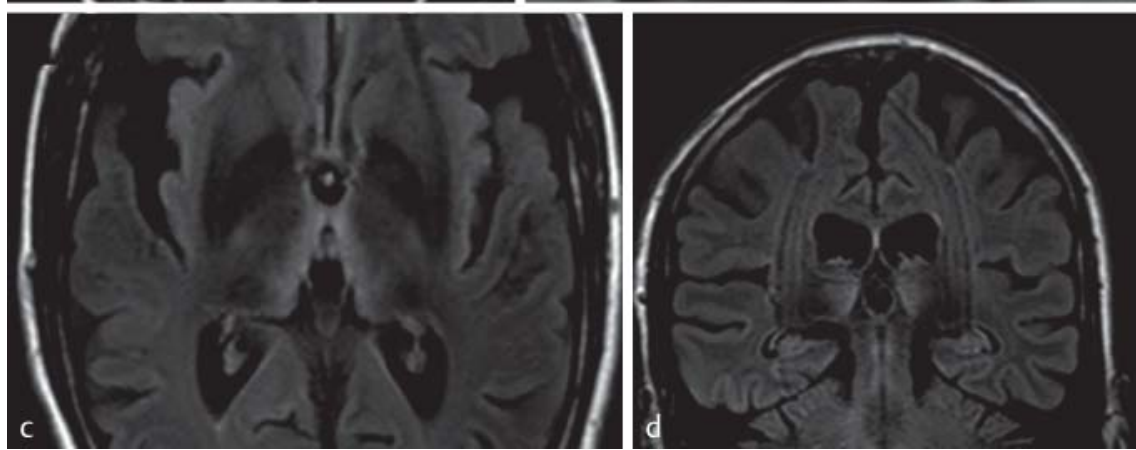

\section{Avitaminosis}

Alcoholism is a risk factor for alimentary and malabsorption-based hypovitaminosis primarily caused by a deficiency of B vitamins. It is important to know that hypovitaminosis is frequently not associated with alcohol abuse but nonetheless results in "typical" visible morphological changes [23]. Therefore, for example, up to $81 \%$ of a cohort of patients with Wernicke encephalopathy (see below) did not have a history of alcohol abuse [24]. Differences in the clinical manifestation of the disease depending on whether there is an alcoholic or non-alcoholic genesis have been described [25]. At this point it is vital to remember that the optic nerve and retina are also part of the CNS and alcohol abuse or alcohol-induced hypovitaminosis are suspected of being able to trigger toxic amblyopia (alcohol amblyopia) [26]. A complete examination of the CNS for alcohol-induced changes should therefore include an ophthalmological examination.

Wernicke encephalopathy/Wernicke-Korsakoff syndrome Wernicke encephalopathy (WE) manifests with a - rarely complete - subacute triad of oculomotor impairments (nystagmus and internuclear ophthalmoplegia), gait ataxia, and impaired consciousness. Vegetative dysregulation typically accompanies this triad. HIV infection is a risk factor for development of the disease $[11,23,24]$.

The main symptoms of Korsakoff syndrome (KS) are anterograde amnesia and retrograde amnesia going back over multiple years in some cases, lack of drive, and impairment of executive functions. Gaps in memory are often filled with fabricated information (confabulations). Severely impaired consciousness is rare. WE becomes chronic KS in 56\% to $81 \%$ of cases and can thus be viewed as an acute form of KS [24].

WE and KS are based on a lack of energy in the CNS caused by a thiamine deficiency that occurs already after approximately 18 days in the case of an absolute cessation of absorption [23]. A secondary hyperhomocysteinemia (>15 $\mu \mathrm{mol} / \mathrm{L} \mathrm{i.S.)}$ has a proapoptotic effect on neural and glial cells [27]. Since glutamate release increases as a consequence of thiamine deficiency and alcohol abuse triggers an overexpression of NMDA receptors, the combination of abuse and thiamine deficiency contributes to particularly severe excitotoxic cell damage. Magnesium deficiency, hyperglycemia, and genetic vulnerability are discussed as aggravating cofactors [18, 28, 29].

The visible morphological changes overlap largely in both diseases. Since there is often also an overlap in clinical symptoms, the term "Wernicke-Korsakoff syndrome" (WKS) is used.

CT imaging is usually not productive. Patients should ideally be examined with MRI $[24,30]$. Focal cerebral edema and in severe cases blood-brain barrier disruption as well as restricted diffusion can be detected on MRI in both diseases. Edema can typically be observed in the medial thalamus and hypothalamus, the periaqueductal gray, the reticular formation, and in the region of the inferior colliculi ( 1 Fig.4a-d, 5a-c). The amygdala and cortex can also be affected. In the case of bilateral signal changes in the dorsomedial thalamus, these may be misinterpreted as an artery of percheron infarction. In fulminant cases, hemorrhage can be observed in SWI or gradient echo sequences ( $\bullet$ Fig. 5 d). In addition, a signal increase of the mammillary bodies on T2-weighted images that can be accompanied by contrast enhancement is considered pathognomonic for the disease ( $\bullet$ Fig. 4b). However, even changes in the mammillary body do not necessarily occur ( $\bullet$ Fig. 5b).

Focal brain atrophy of the affected structures is the lead imaging finding in chronic courses of WKS. Atrophy of the hippocampal-diencephalic and mammillothalamic pathways and of the hippocampi is an anatomical correlate of amnesia in WKS with alterations similar to those of Alzheimer's patients [31]. Quantitative MRI methods were able to detect focal changes in cerebral blood flow (CBF) [32, 33]. It must be taken into consideration that many clinically unequivocal cases of WKS lack a correlate on MRI. The sensi- 

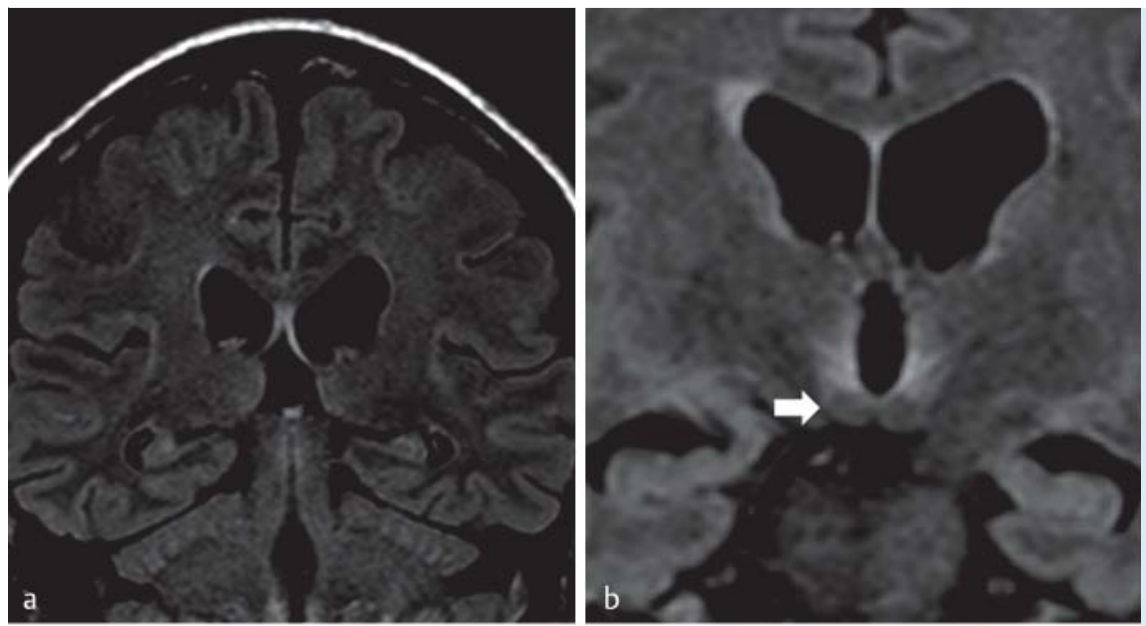

Fig. 5 Wernicke-Korsakoff syndrome in a patient with acute myeloid leukemia. Non-alcohol addicted patient with thiamine malresorption under chemotherapy for AML. Vestibulo-cerebellar ataxia and tremor started approx. 20 days after admission. On FLAIRw images, subtly signal-elevated lesions in the periaqueductal gray matter and the fornix $\mathbf{a}$, the hypothalamus $\mathbf{b}, \mathbf{c}$ and along the walls of the third ventricle a-c. N.B. The mammillary bodies are spared in this case (arrow, b). On follow-up MRI, SWIw images show hypothalamic hemorrhage despite thiamine substitution $\mathbf{d}$.
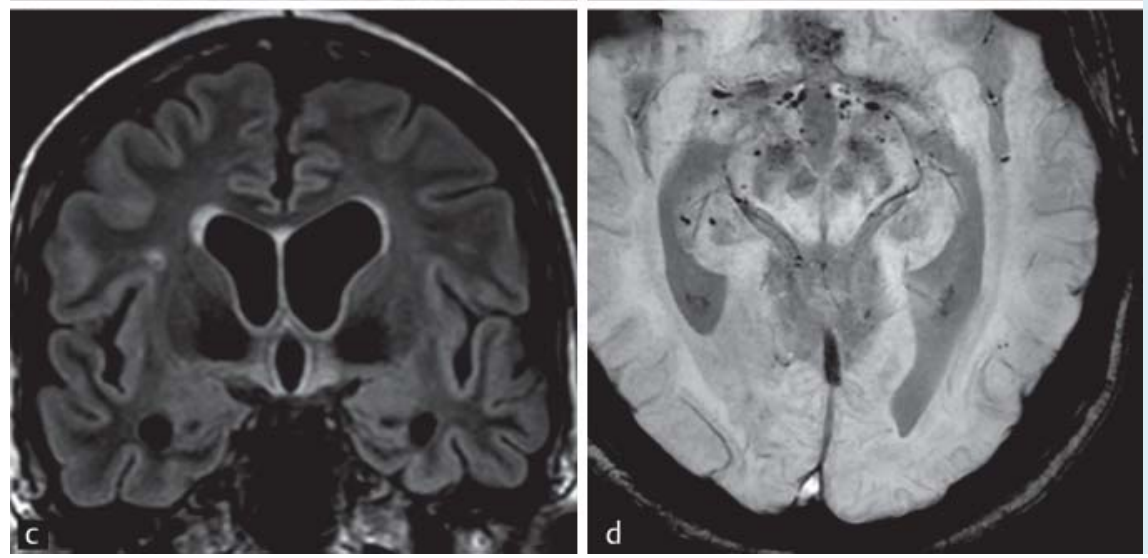

tivity in one study was only $53 \%$. In contrast, the specificity for MRI is very high [34].

\section{Marchiafava-Bignami syndrome}

Marchiafava-Bignami syndrome is an extremely rare acute demyelinating disease of the corpus callosum. Acute disorientation with amnesia which can deteriorate to delirium or coma and may result in death is the key symptom. Since the corpus callosum is involved, disconnection symptoms as in split-brain patients are possible. A rapidly progressing form in chronic alcohol abuse (approx. 90\% of all cases) can be differentiated from a non-alcohol-induced pseudoform with a significantly better prognosis [35]. The alcohol-induced form is not necessarily triggered by acute intoxication. In the largest Marchiafava-Bignami study to date, patients with the non-alcohol-induced pseudoform fully recovered in over $80 \%$ of cases. The reverse was true in alcohol-induced cases in which $89 \%$ of patients had long-term neurological damage or died [35].

Etiologically the disease may be the result of a thiamine or vitamin B complex deficiency. However, the pathogenesis has not been sufficiently understood [35].

Diagnosis should be primarily made via MRI. Edematous lesions of the corpus callosum are an indicative change. However, DWI is often as suitable as T2-weighted sequences for detecting changes [36, 37]. In contrast to the alcohol-induced form, the pseudoform usually exclusively affects the central splenium ( $\bullet$ Fig.6a-c) [35], Isolated edematous affection of the splenium is prognostically favorable in MarchiafavaBignami syndrome. However, extensive lesions, contrast en- hancement, hemorrhages, and focal hypoperfusion are prognostically unfavorable as are extracallosal, e.g. cortical, lesions [35, 38]. Fiber tracking via DTI can be used for followup [39].

\section{Funicular myelosis/posterior column degeneration}

Funicular myelosis is primarily a disease of the posterior columns of the cervical and thoracic spinal cord. Dysfunction of deep sensitivity and movement coordination are clinical findings. However, mental changes and paralytic symptoms can occur over the disease course. Glossitis is often also detectable ("Hunter's glossitis")

Funicular myelosis is caused by a cobalamin deficiency (vitamin B12), e. g. in the case of a lack of intrinsic factor production, due to gastritis or malnutrition. Malabsorption can be triggered toxically after exposure to nitric oxide (NO). Funicular myelosis develops slowly since vitamin B12 stores last up to two years. Since alcohol abuse is only one of many causes of an insufficient supply and malabsorption of vitamin B12, it must be assumed that the majority of cases of funicular myelosis are not due to alcohol abuse. However, no studies regarding frequence distribution of etiology are available to our knowledge. A vitamin B12 deficiency can be detected via serum testing. Malabsorption can be detected via the Schilling test with radioactively-labeled vitamin B12.

The changes cannot be discriminated on CT but appear on MRI in the acute stage as edema of the posterior columns ( $\odot$ Fig. 7a). Secondary bleeding of spinal cord lesions can occur and tissue defects can develop. In the early stages, some of the changes are reversible ( $\bullet$ Fig. $\mathbf{7 b}$ ). In cases of pro- 

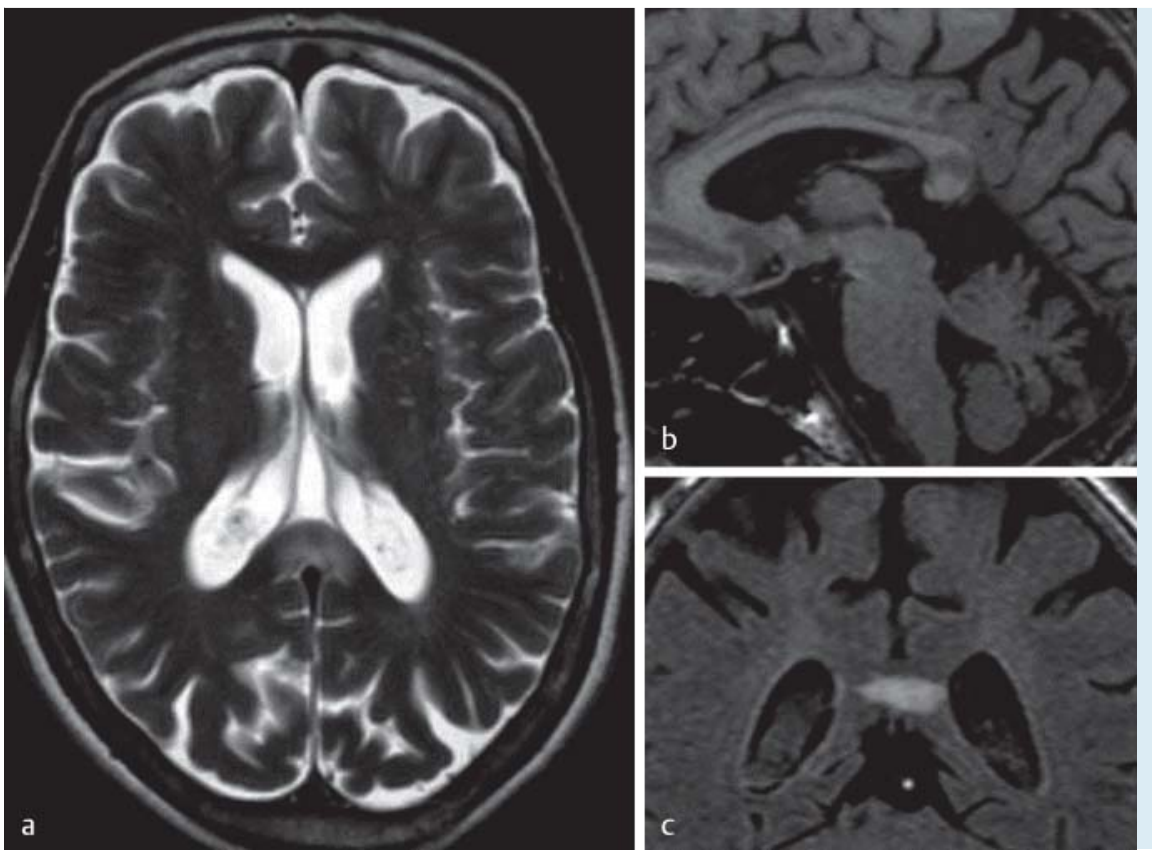

Fig. 6 Marchiava-Bignami syndrome. Female patient with bipolar disorder and long-standing alcohol abuse. Acute onset of apraxia. Detection of edema in the splenium on T2wa, T1w $\mathbf{b}$ and FLAIRw c images. Further global brain atrophy especially of the superior cerebellum as a consequence of chronic alcohol abuse $\mathbf{b}, \mathbf{c}$.

longed vitamin B12 depletion, the posterior columns atrophy and extraspinal manifestations can occur [40]. It must be taken into consideration that (nursing) infants of mothers with suspicion of a vitamin B12 deficiency can show clinically manifest symptoms that do not primarily affect the posterior columns but rather the cortex in terms of cerebral atrophy [41].

In the case of a lack of response to vitamin B12 substitution, the rare differential diagnosis of copper deficiency myelopathy which cannot be clinically or visually differentiated from funicular myelosis should be considered. Copper substitution should be considered after copper deficiency was proven in a lab test. Copper deficiency can also be caused by chronic zinc poisoning which is absorbed competitively to copper and increases the enteral elimination of copper ions [42]. A nowadays very rare differential diagnosis is poliomyelitis (with a different clinical course) which exclusively affects the anterior horn cells and spares the posterior columns ( $\bullet$ Fig. 7c).

\section{Dynamics and reversibility of the changes}

Even a single instance of excessive alcohol consumption can cause an acute global brain volume decrease due to increased diuresis which is completely reversible within a maximum of two weeks [43].

Is there a lower consumption limit regarding the formation of chronic CNS changes? It is difficult to answer this question. Answering is complicated by the fact that there is no generally accepted definition of "low" or "substantial" alcohol consumption. Every healthcare authority and almost every study define different limits. In male subjects with a consumption of a maximum of $36 \mathrm{~g}$ of ethyl alcohol per week, no changes in comparison to the abstinent control group could be shown [44]. However, this quantity corresponds to 0.91 beer with a $5 \%$ alcohol content. In contrast, another study with higher limits for "low consumption" could show a decrease of brain volume even at the lowest level of consumption [45].
However, if changes have already occurred, it is important for physicians as well as patients to know that atrophy is at least partially reversible even in the case of long-standing alcohol abuse. An increase in white matter could be detected as early as a few days after the start of alcohol abstinence. The degree of restitution depended primarily on the duration of abstinence and not on the duration of addiction [46, 47].

Not only the focal distribution of alcohol in the brain and changes in cellular metabolites such as aspartate but also the regeneration of the brain tissue under oxidative stress in the case of abstinence in chronic abuse can be dynamically detected on magnetic resonance spectroscopy and correlate with clinical recovery [48-50]. Cerebral regeneration in the case of abstinence is reflected in a focally differentiated increase in the choline and NAA peaks [51].

\section{Alcohol in the developing brain: Fetal alcohol syndrome} Despite numerous campaigns, up to $20 \%$ of pregnant women in Germany regularly drink alcohol [52]. They are often not aware that alcohol causes particularly significant and long-term damage of the brain in the fetal development phase $[53,54]$. Therefore, a number of up to 100000 children and adolescents with fetal alcohol syndrome is assumed to live in Germany [55]. Retinal damage due to fetal alcohol exposure (in terms of already described alcohol amblyopia) could be observed in an animal model [56].

Fetal alcohol syndrome (FAS) with typical facial stigmata such as a thin upper lip and flattened philtrum affects approx. $0.1 \%$ of all neonates depending on the population observed.

Children with FAS frequently suffer from neurological symptoms that demand clarification via MRI, e.g. epilepsy. A global low brain volume and structural abnormalities of the corpus callosum were detected in FAS children compared to non-exposed control groups $[53,57]$. However, reduced or retarded myelination, gyration disorders, reduced hippocampal and cerebellar volumes and reduced 

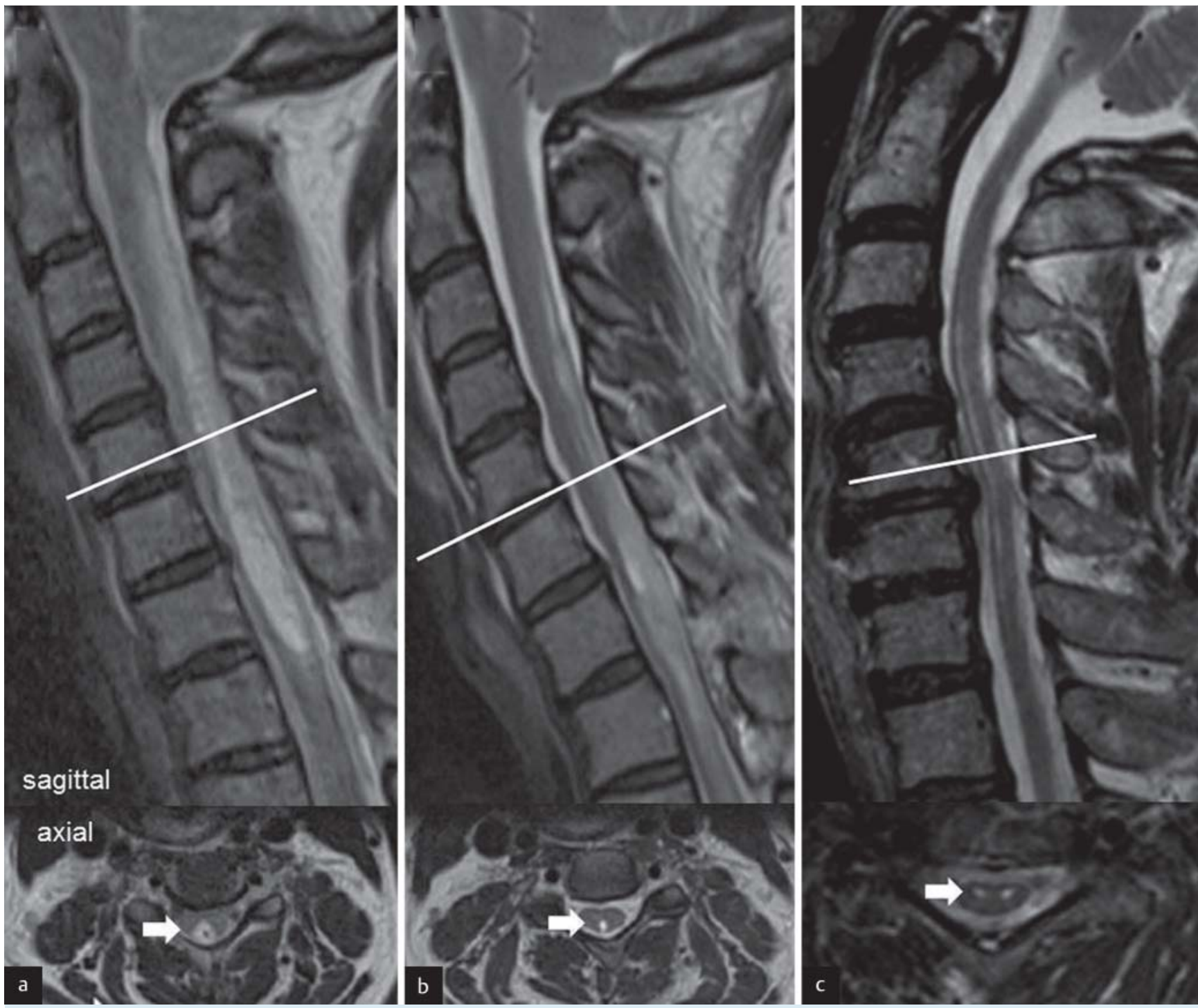

Fig. 7 Funicular myelosis. Funicular myelosis: 72-year-old patient with alcohol abuse and chronic malnutrition. Deteriorating sensory loss and atactic gait. On initial T2w MRI images a detection of cystic and edematous swelling of the dorsal cervical spinal cord (arrow). Glioma and infarction were considered as differential diagnoses. The lesions were partially remit-

ting after 6 weeks of vitamin B12 and folic acid substitution (b, arrow). Differential diagnosis post-polio syndrome $\mathbf{c}$ : Similar circumscribed spinal cord lesions, but of the anterior gray column, can be seen in post-polio syndrome. connectivity were also frequently observed [33, 58-61]. Magnetic resonance spectroscopy studies showed reduced NAA peaks both globally and in the cerebellum $[62,63]$. Microcephaly defined as a cephalic growth rate below the 10th percentile is currently the only visible morphological feature recognized as a diagnostic criterion for FAS. Similar to the situation in adult alcohol addicts, the lack of specificity of CNS changes complicates the finding of MR imaging features that are unequivocally a consequence of alcohol abuse. In this respect, MRI has not (yet?) been included in to the officially recognized diagnostic guidelines for FAS [55].

\section{Alcohol abuse and cerebral aneurysms}

The effect of lifestyle factors on the rupture risk of cerebral aneurysms has long been the subject of intensive research and is partly contradictory concerning alcohol. In patients with unruptured aneurysms, chronic alcohol abuse was identified as an independent risk factor for early death (ha- zard ratio 4.1) in a recent study [64]. The increased mortality rate of patients classified as "heavy drinkers" (>330 g pure alcohol/week) was not attributed to an increased rupture risk. Yet, while a large metaanalysis with 892 patients from multiple studies showed that chronic alcohol consumption of more than $150 \mathrm{~g}$ pure alcohol/week significantly increased the rupture risk particularly for women, alcohol abuse was not able to be identified in other studies as a significant risk factor for rupture [65-67]. However, acute consumption seems to increase the rupture risk significantly and proportionally to the dose for a short period of 24 hours [68].

Regarding that alcohol may increase the rupture risk of intracranial aneurysms and the relatively high prevalence of aneurysms (around 3\% of the population) time-of-flight angiography of the intracranial arteries should be considered in cases of cranial MRI for patients with (suspected) alcohol abuse. 


\section{Summary}

$\nabla$

CT and in particular MRI detect most cases of secondary CNS damage occurring as a result of alcohol abuse. However, the damage patterns are rarely alcohol-specific. The complex and often overlapping pathologies make exact knowledge of the pathophysiology as well as information about the individual clinical symptoms necessary to achieve exact diagnosis. In particular, radiological research should have a greater focus on the improvement of imaging in fetal alcohol syndrome and the evaluation of the alcohol abuse as a risk factor for patients with intracranial aneurysms alcohol in the future.

\section{References}

1 Drogen- und Suchtbericht 2014; 2015, http://www.drogenbeauftragte. de/fileadmin/dateien-dba/Presse/Downloads/Drogen-_und_Suchtbericht_2014_Gesamt_WEB_07.pdf

2 Sripathirathan K, Brown J 3rd, Neafsey EJ et al. Linking binge alcohol-induced neurodamage to brain edema and potential aquaporin-4 upregulation: evidence in rat organotypic brain slice cultures and in vivo. Journal of neurotrauma 2009; 26: 261-273

3 Dodd PR, Beckmann AM, Davidson MS et al. Glutamate-mediated transmission, alcohol, and alcoholism. Neurochemistry international 2000; 37: 509-533

4 Adams RD, Victor M, Mancall EL. Central pontine myelinolysis: a hitherto undescribed disease occurring in alcoholic and malnourished patients. AMA archives of neurology and psychiatry 1959; 81: 154-172

5 Gocht A, Colmant HJ. Central pontine and extrapontine myelinolysis: a report of 58 cases. Clinical neuropathology 1987; 6: 262-270

6 Brown WD. Osmotic demyelination disorders: central pontine and extrapontine myelinolysis. Current opinion in neurology 2000; 13: $691-697$

7 Gankam Kengne F, Nicaise C, Soupart A et al. Astrocytes are an early target in osmotic demyelination syndrome. Journal of the American Society of Nephrology: JASN 2011; 22: 1834-1845

8 Martin RJ. Central pontine and extrapontine myelinolysis: the osmotic demyelination syndromes. Journal of neurology, neurosurgery, and psychiatry 2004; 75 (Suppl 3): iii22 - iii28

9 Vaquero J, Chung C, Cahill ME et al. Pathogenesis of hepatic encephalopathy in acute liver failure. Seminars in liver disease 2003; 23: 259269

10 Rovira A, Alonso J, Cordoba J. MR imaging findings in hepatic encephalopathy. AJNR American journal of neuroradiology 2008; 29: $1612-$ 1621

11 Butterworth RF. Hepatic encephalopathy-a serious complication of alcoholic liver disease. Alcohol research \& health: the journal of the National Institute on Alcohol Abuse and Alcoholism 2003; 27: 143-145

12 Burkhard PR, Delavelle J, Du Pasquier $R$ et al. Chronic parkinsonism associated with cirrhosis: a distinct subset of acquired hepatocerebral degeneration. Archives of neurology 2003; 60: 521-528

13 Pfefferbaum A, Lim KO, Zipursky RB et al. Brain gray and white matter volume loss accelerates with aging in chronic alcoholics: a quantitative MRI study. Alcoholism, clinical and experimental research 1992; 16 : $1078-1089$

14 Niemela 0 . Distribution of ethanol-induced protein adducts in vivo: relationship to tissue injury. Free radical biology \& medicine 2001; 31: $1533-1538$

15 Smith KJ, Butler TR, Prendergast MA. Ethanol impairs microtubule formation via interactions at a microtubule associated protein-sensitive site. Alcohol 2013; 47: 539-543

16 Lamarche F, Gonthier B, Signorini N et al. Impact of ethanol and acetaldehyde on DNA and cell viability of cultured neurones. Cell biology and toxicology 2004; 20 : $361-374$

17 Alfonso-Loeches S, Pascual M, Gomez-Pinedo U et al. Toll-like receptor 4 participates in the myelin disruptions associated with chronic alcohol abuse. Glia 2012; 60: 948 -964

18 Blansjaar BA, Vielvoye GJ, van DijkJG et al. Similar brain lesions in alcoholics and Korsakoff patients: MRI, psychometric and clinical findings. Clinical neurology and neurosurgery 1992; 94: 197-203
19 Sullivan EV, Pfefferbaum A. Neuroimaging of the Wernicke-Korsakoff syndrome. Alcohol and alcoholism 2009; 44: 155-165

20 Harper C, Matsumoto I. Ethanol and brain damage. Current opinion in pharmacology 2005; 5: 73-78

21 Sullivan EV, Deshmukh A, Desmond JE et al. Cerebellar volume decline in normal aging, alcoholism, and Korsakoff's syndrome: relation to ataxia. Neuropsychology 2000; 14: $341-352$

22 Lewandowska E, Kujawa M, Jedrzejewska A. Ethanol-induced changes in Purkinje cells of the rat cerebellum. I. The ultrastructural changes following chronic ethanol intoxication (qualitative study). Folia neuropathologica / Association of Polish Neuropathologists and Medical Research Centre, Polish Academy of Sciences 1994; 32: 51-59

23 Sechi G, Serra A. Wernicke's encephalopathy: new clinical settings and recent advances in diagnosis and management. The Lancet Neurology 2007; 6: $442-455$

24 Lough ME. Wernicke's encephalopathy: expanding the diagnostic toolbox. Neuropsychology review 2012; 22: 181 - 194

25 Scalzo SJ, Bowden SC, Ambrose ML et al. Wernicke-Korsakoff syndrome not related to alcohol use: a systematic review. Journal of neurology, neurosurgery, and psychiatry 2015; DOI: 10.1136/jnnp-2014-309598

26 Chiotoroiu SM, Noaghi M, Stefaniu GI et al. Tobacco-alcohol optic neuropathy-clinical challenges in diagnosis. Journal of medicine and life 2014; 7: 472-476

27 Langmeier M, Folbergrova J, Haugvicova R et al. Neuronal cell death in hippocampus induced by homocysteic acid in immature rats. Epilepsia 2003; 44: 299-304

28 Zelaya FO, Rose SE, Nixon PF et al. MRI demonstration of impairment of the blood-CSF barrier by glucose administration to the thiamin-deficient rat brain. Magnetic resonance imaging 1995; 13: 555-561

29 Blass JP, Gibson GE. Abnormality of a thiamine-requiring enzyme in patients with Wernicke-Korsakoff syndrome. The New England journal of medicine 1977; 297: 1367 - 1370

30 Galvin R, Brathen $G$, Ivashynka $A$ et al. EFNS guidelines for diagnosis, therapy and prevention of Wernicke encephalopathy. European journal of neurology: the official journal of the European Federation of Neurological Societies 2010; 17: 1408 - 1418

31 Sullivan EV, Marsh L. Hippocampal volume deficits in alcoholic Korsakoff's syndrome. Neurology 2003; 61: 1716-1719

32 Meyer JS, Tanahashi N, Ishikawa Y et al. Cerebral atrophy and hypoperfusion improve during treatment of Wernicke-Korsakoff syndrome. Journal of cerebral blood flow and metabolism: official journal of the International Society of Cerebral Blood Flow and Metabolism 1985; 5 : 376-385

33 Benson DF, Djenderedjian A, Miller BL et al. Neural basis of confabulation. Neurology 1996; 46: 1239-1243

34 Antunez E, Estruch R, Cardenal C et al. Usefulness of CT and MR imaging in the diagnosis of acute Wernicke's encephalopathy. Am J Roentgenol 1998; $171: 1131-1137$

35 Hillbom M, Saloheimo P, Fujioka S et al. Diagnosis and management of Marchiafava-Bignami disease: a review of CT/MRI confirmed cases. Journal of neurology, neurosurgery, and psychiatry 2014; 85: 168 173

36 Hlaihel C, Gonnaud PM, Champin S et al. Diffusion-weighted magnetic resonance imaging in Marchiafava-Bignami disease: follow-up studies. Neuroradiology 2005; 47: 520-524

37 Aggunlu L, Oner Y, Kocer B et al. The value of diffusion-weighted imaging in the diagnosis of Marchiafava-Bignami disease: apropos of a case. Journal of neuroimaging: official journal of the American Society of Neuroimaging 2008; 18: $188-190$

38 Namekawa M, Nakamura Y, Nakano I. Cortical involvement in Marchiafava-Bignami disease can be a predictor of a poor prognosis: a case report and review of the literature. Internal medicine 2013; 52: 811 813

39 Sair HI, Mohamed FB, Patel S et al. Diffusion tensor imaging and fibertracking in Marchiafava-Bignami disease. Journal of neuroimaging: official journal of the American Society of Neuroimaging 2006; 16: 281 285

40 Kealey SM, Provenzale JM. Tensor diffusion imaging in B12 leukoencephalopathy. Journal of computer assisted tomography 2002; 26: $952-$ 955

41 Kocaoglu C, Akin F, Caksen H et al. Cerebral atrophy in a vitamin B12deficient infant of a vegetarian mother. Journal of health, population, and nutrition 2014; 32: 367-371 
42 Zittel S, Ufer F, Gerloff C et al. Severe myelopathy after denture cream use-is copper deficiency or excess zinc the cause? Clinical neurology and neurosurgery 2014; $121: 17-18$

43 Zipursky RB, Lim KC, Pfefferbaum A. MRI study of brain changes with short-term abstinence from alcohol. Alcoholism, clinical and experimental research 1989; 13: 664-666

44 Meyerhoff DJ, Bode C, Nixon SJ et al. Health risks of chronic moderate and heavy alcohol consumption: how much is too much? Alcoholism, clinical and experimental research 2005; 29: $1334-1340$

45 Paul CA, Au R, Fredman L et al. Association of alcohol consumption with brain volume in the Framingham study. Archives of neurology 2008; 65: $1363-1367$

46 Monnig MA, Caprihan A, Yeo RA et al. Diffusion tensor imaging of white matter networks in individuals with current and remitted alcohol use disorders and comorbid conditions. Psychology of addictive behaviors: journal of the Society of Psychologists in Addictive Behaviors 2013; 27: $455-465$

47 Pfefferbaum A, Sullivan EV, Mathalon DH et al. Longitudinal changes in magnetic resonance imaging brain volumes in abstinent and relapsed alcoholics. Alcoholism, clinical and experimental research 1995; 19: $1177-1191$

48 Schauss G, Schild H, Urban R et al. 1H-MR spectroscopic imaging: an approach to evaluating alcohol breakdown in the brain. RoFo: Fortschritte auf dem Gebiete der Röntgenstrahlen und der Nuklearmedizin 1994; 160: 493 - 499

49 Zahr NM, Mayer D, Rohlfing T et al. Brain injury and recovery following binge ethanol: evidence from in vivo magnetic resonance spectroscopy. Biological psychiatry 2010; 67: 846-854

50 Schweinsburg BC, Taylor MJ, Alhassoon OM et al. Chemical pathology in brain white matter of recently detoxified alcoholics: a $1 \mathrm{H}$ magnetic resonance spectroscopy investigation of alcohol-associated frontal lobe injury. Alcoholism, clinical and experimental research 2001; 25: 924-934

51 Bartsch AJ, Homola G, Biller A et al. Manifestations of early brain recovery associated with abstinence from alcoholism. Brain: a journal of neurology 2007; 130: 36-47

52 Bergmann KE, Bergmann RL, Ellert $U$ et al. Perinatal risk factors for longterm health. Results of the German Health Interview and Examination Survey for Children and Adolescents (KiGGS). Bundesgesundheitsblatt, Gesundheitsforschung, Gesundheitsschutz 2007; 50: 670-676

53 Lebel C, Rasmussen C, Wyper $K$ et al. Brain diffusion abnormalities in children with fetal alcohol spectrum disorder. Alcoholism, clinical and experimental research 2008; 32: $1732-1740$

54 Petit G, Maurage P, Kornreich C et al. Binge drinking in adolescents: a review of neurophysiological and neuroimaging research. Alcohol and alcoholism 2014; 49: 198-206
55 Landgraf MN, Nothacker M, Heinen F. Diagnosis of fetal alcohol syndrome (FAS): German guideline version 2013. European journal of paediatric neurology: EJPN: official journal of the European Paediatric Neurology Society 2013; 17: 437-446

56 Lantz CL, Pulimood NS, Rodrigues-Junior WS et al. Visual defects in a mouse model of fetal alcohol spectrum disorder. Frontiers in pediatrics 2014; $2: 107$

57 Bookstein FL, Connor PD, Huggins JE et al. Many infants prenatally exposed to high levels of alcohol show one particular anomaly of the corpus callosum. Alcoholism, clinical and experimental research 2007; 31: $868-879$

58 Astley SJ, Aylward EH, Olson HC et al. Magnetic resonance imaging outcomes from a comprehensive magnetic resonance study of children with fetal alcohol spectrum disorders. Alcoholism, clinical and experimental research 2009; 33: 1671 - 1689

59 Nardelli A, Lebel C, Rasmussen C et al. Extensive deep gray matter volume reductions in children and adolescents with fetal alcohol spectrum disorders. Alcoholism, clinical and experimental research 2011; 35: $1404-1417$

60 Coles $C D$, Goldstein $F C$, Lynch ME et al. Memory and brain volume in adults prenatally exposed to alcohol. Brain and cognition 2011; 75 : $67-77$

61 Wozniak JR, Mueller BA, Bell CJ et al. Global functional connectivity abnormalities in children with fetal alcohol spectrum disorders. Alcoholism, clinical and experimental research 2013; 37: $748-756$

62 du Plessis L, Jacobson JL, Jacobson SW et al. An in vivo $1 \mathrm{H}$ magnetic resonance spectroscopy study of the deep cerebellar nuclei in children with fetal alcohol spectrum disorders. Alcoholism, clinical and experimental research 2014; 38: 1330 - 1338

63 Fagerlund A, Heikkinen S, Autti-Ramo I et al. Brain metabolic alterations in adolescents and young adults with fetal alcohol spectrum disorders. Alcoholism, clinical and experimental research 2006; 30: 2097-2104

64 Juvela S, Lehto $H$. Risk factors for all-cause death after diagnosis of unruptured intracranial aneurysms. Neurology 2015; 84: 456-463

65 Feigin VL, Rinkel GJ, Lawes CM et al. Risk factors for subarachnoid hemorrhage: an updated systematic review of epidemiological studies. Stroke: a journal of cerebral circulation 2005; 36: $2773-2780$

66 Vlak MH, Rinkel GJ, Greebe P et al. Independent risk factors for intracranial aneurysms and their joint effect: a case-control study. Stroke: a journal of cerebral circulation 2013; 44: 984-987

67 You SH, Kong DS, Kim JS et al. Characteristic features of unruptured intracranial aneurysms: predictive risk factors for aneurysm rupture. Journal of neurology, neurosurgery, and psychiatry 2010; 81: 479484

68 Juvela S, Porras $M$, Heiskanen $O$. Natural history of unruptured intracranial aneurysms: a long-term follow-up study. Journal of neurosurgery 1993; 79: $174-182$ 